\title{
Economic efficiency of the introduction of the automated locomotive reliability management system
}

\author{
Viktoriya A. Olentsevich ${ }^{1, *}$ Viktor V. Kondratiev ${ }^{2}$, Boris $O$. Kuznetsov ${ }^{1}$, and Antonina I. Karlina ${ }^{2}$ \\ ${ }^{1}$ Irkutsk State Transport University, 15, Chernyshevsky Str., Irkutsk, Russia, \\ ${ }^{2}$ Irkutsk National Research Technical University, 83, Lermontov Str., Irkutsk, Russia
}

\begin{abstract}
Railway transport has its characteristic features: a specific investment structure, its relatively high capital intensity and duration of implementation of innovative projects, technological continuity of the production process, and much more. The specified features are also appropriate to service locomotive depots and actively influence the development of methodological approaches to assessing the economic efficiency of innovative projects. Of course, the main task of innovative projects is not to increase their number, but to increase the long-term efficiency of the transport company. To achieve this goal, according to the authors, it is advisable to use the balanced scorecard (BSC), which is an element of the company's strategic management, but it must be adapted to innovative projects. The use of the balanced scorecard in the service locomotive depot of the railway transport system will allow the industry to reach a new level of functioning and make it possible to assess the economic efficiency of innovative projects as objectively and accurately as possible. The proposed methodology for assessing the effectiveness of an innovative project makes it possible, on the one hand, to economically justify the project, on the other hand, to monitor production efficiency both for the purposes of the project itself and to stimulate the innovative activity of the enterprise. With that, the result of an innovative project is considered not as static, but as a set of indicators for its implementation, which has specific dynamic, economic, financial, technical, technological and other characteristics.
\end{abstract}

Keywords: railway transport system, service locomotive depot, target map, planning horizon, locomotive yardtime, production efficiency monitoring.

\section{Introduction}

One of the key tasks stipulated by the Strategy for the Development of Railway Transport of the Russian Federation until 2030 is the effective use of the transit potential of Russian railways with reference to the development of sections of international transport corridors passing through the territory of Russia. Its effectiveness of the formation is ensured on the basis of the principle of the proper quality of transportation, including the timeliness of delivery and safety of goods [3. 10].

Ensuring the competitiveness of enterprises of the railway transport system is impossible without carrying out work on their technical re-equipment, the use of modern technologies, the development of new products that are in demand by consumers of transport and related services. It should be borne in mind that these measures, which should be carried out within the entire transport complex, are not effective without a comprehensive solution of problems aimed at improving the management system, labor organization, the introduction of advanced practices in the scientific organization of labor and modernization, equipment maintenance $[2,6,11]$.
The locomotive complex, as one of the key links in the production unit of Russian Railways OAO, significantly affects the overall efficiency of the Company and cannot be kept out of the ongoing transformations. The main functions of repair enterprises and sectors in the railway transport system are to perform the following types of work: ensuring the technical functional state of equipment (and other fixed assets); reduction of unproductive yardtime of rolling stock; reduction of repair and maintenance costs while maintaining the repair quality; scientifically substantiated specification of labor costs for individual operations to perform repair and restoration work; automation of production processes, etc. [8].

Analysis of the world experience of operating the locomotive fleet shows that the most successful relationship model is that one, in which the manufacturer of this equipment bears the main responsibility for the technical condition throughout the entire life cycle of the locomotive to its owner. When introducing this procedure, rolling stock manufacturers have additional incentives: to invest in improving the locomotive design; increasing the level of its reliability and uninterrupted operation; supply of the necessary modern technological

* Corresponding author: olencevich_va@mail.ru 
equipment; automation of the production cycle; staff motivation $[7,13,15]$.

The use of BSC in a service locomotive depot will allow the enterprise to reach a new level of functioning and will make it possible to assess the economic efficiency of innovative projects as objectively and accurately as possible.

\section{Problem Statement}

Using a balanced scorecard (BSC) in estimating economic efficiency of the introduction of the automated locomotive reliability management system

\section{Research Questions}

The BSC target map is applicable to the service locomotive depot

BSC works on the basis of measuring and evaluating performance according to a set of optimally selected indicators that measure the goals of an innovative project and reflect all its aspects, both financial and nonfinancial. Therefore, one of the most important measures in the preparation of the BSC application is the selection of key performance indicators (Key Performance Indicators, KPIs), since the use of the selected indicators will make it possible to make the goals of the innovation project more specific and measurable $[1,5,12]$.

The number of areas considered in the BSC may vary, and therefore it is advisable to use this system in relation to the service locomotive depot in three main areas: finance, internal business processes and personnel management.

In these areas it is necessary to clearly formulate the ultimate goals that are pursued by the service locomotive depot as part of an innovative project. For example, in the direction of "finance" it is advisable to choose the profitability of an innovative project as the main goal, since it is the achievement of this goal that will lead to the successful implementation of the project as a whole. In the direction of "business processes" it is necessary to improve, first of all, critical internal production processes. Thus, the following goals can be formed in this direction: improving the quality of technical inspection and current repair of locomotives, as well as reducing the yardtime of locomotives for these types of repairs.

In the area of "personnel and systems", the perspective of personnel training and increasing the level of automation are designed to provide long-term growth and improvement.

Based on the above, we will draw up a map of BSC goals applicable to a service locomotive depot (Fig. 1).
F - Finances

I - Business processes

\section{$\mathrm{L}$ - Personnel and systems}

Profitability of an innovative project

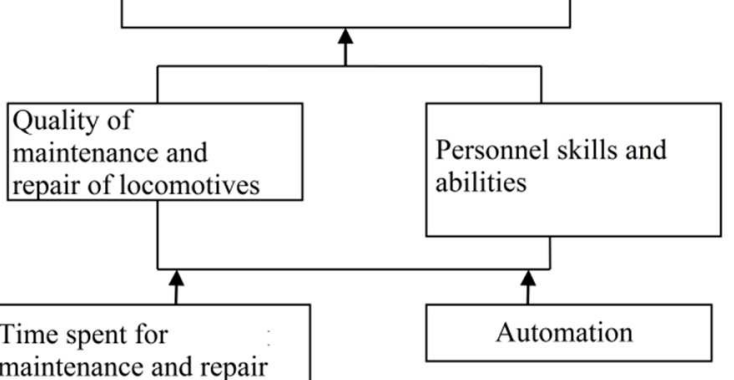

Figure 1. BSC target map for a service locomotive depot

After setting the BSC goals, it is necessary to establish a set of indicators, with the help of which we will evaluate the effectiveness of achieving each of the goals and the entire innovative project, table 1 .

Table 1. Key Performance Indicators (KPI)

\begin{tabular}{|c|l|l|}
\hline Direction & \multicolumn{1}{|c|}{ Goals } & \multicolumn{1}{c|}{ KPI Indicators } \\
\hline F & $\begin{array}{l}\text { F1. Profitability of an } \\
\text { innovative project }\end{array}$ & $\begin{array}{l}\text { Net present value, NPV } \\
\text { Discounted project } \\
\text { payback period, DPP }\end{array}$ \\
\hline I & $\begin{array}{l}\text { I1. Reducing the time } \\
\text { for maintenance and } \\
\text { repair of locomotives }\end{array}$ & $\begin{array}{l}\text { Yardtime of } \\
\text { locomotives for } \\
\text { unscheduled repairs }\end{array}$ \\
\cline { 2 - 3 } & $\begin{array}{l}\text { I2. Improving the } \\
\text { quality of maintenance } \\
\text { and repair of } \\
\text { locomotives }\end{array}$ & $\begin{array}{l}\text { Locomotive technical } \\
\text { availability coefficient }\end{array}$ \\
\hline L & L1. Automation & Automation level \\
\hline
\end{tabular}

The proposed methodology for assessing the effectiveness of an innovative project makes it possible, on the one hand, to economically justify the project, on the other hand, to monitor production efficiency both for the purposes of the project itself and to stimulate the innovative activity of the enterprise. With that, the result of an innovative project is considered not as static, but as a set of indicators for its implementation, which has specific dynamic, economic, financial, technical, technological and other characteristics $[9,14,16]$.

Assessment of the economic efficiency of the introduction of an automated system for locomotive reliability management based on the proposed method.

Based on the proposed methodology, using the balanced scorecard system (BSC) developed by the authors in relation to the service locomotive depot, we will assess the economic efficiency of the introduction of the automated locomotive reliability management system (ALRMS) in the railway transport system. 
The first indicator to be assessed within the BSC is net present value (NPV). To calculate it, you need a cash flow $(\mathrm{CF})$ determined by the formula (1):

$C F=C I-C O$,

where CI (Cash Inflows) is the cash inflow;

$\mathrm{CO}$ (Cash Outflows) is the cash outflow.

As previously noted, the planning horizon is 5 years. In this case the discount rate (r) equal to $10 \%$ is taken to determine the discounted cash flows. Calculations are given in table 2 .

Table 2. Determination of net present value (NPV)

\begin{tabular}{|c|c|c|c|c|c|}
\hline 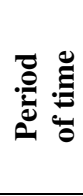 & 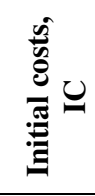 & च & 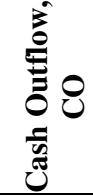 & 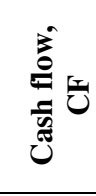 & 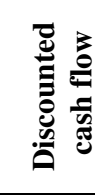 \\
\hline 0 & 3.494 & - & - & - & - \\
\hline 1 & - & 3.274 & 5.558 & -2.284 & -2.077 \\
\hline 2 & - & 3.616 & 3.835 & -0.218 & -0.180 \\
\hline 3 & - & 4.345 & 1.976 & 2.369 & 1.780 \\
\hline 4 & - & 4.172 & 1.219 & 2.953 & 2.017 \\
\hline 5 & - & 4.236 & 0.384 & 3.852 & 2.392 \\
\hline \multicolumn{5}{|c|}{ NPV } & 0.437 \\
\hline
\end{tabular}

$$
\begin{gathered}
\mathrm{NPV}=(-2.077-0.18+1.78+2.017+2.392)-3.494= \\
=0.437 \text { million rubles }
\end{gathered}
$$

The net discounted income from the implementation of ALRMS is greater than zero and is equal to 0.437 million rubles, which indicates the attractiveness of the investment project, while the project provides coverage of future costs.

The next indicator that needs to be assessed in the framework of the BSC is the discounted payback period of the project (Table 3 ).

Table 3. Determining the discounted payback period (DPP)

\begin{tabular}{|c|c|c|c|c|}
\hline $\begin{array}{c}\text { Period } \\
\text { of time }\end{array}$ & $\begin{array}{c}\text { Initial } \\
\text { costs, IC }\end{array}$ & $\begin{array}{c}\text { Cash } \\
\text { flow, CF }\end{array}$ & $\begin{array}{c}\text { Discounted } \\
\text { cash flow }\end{array}$ & $\begin{array}{c}\text { Discounted } \\
\text { cash flow } \\
\text { running total }\end{array}$ \\
\hline 0 & 3.494 & - & - & - \\
\hline 1 & - & -2.284 & -2.077 & -2.077 \\
\hline 2 & - & -0.218 & -0.180 & -2.257 \\
\hline 3 & - & 2.369 & 1.780 & -0.477 \\
\hline 4 & - & 2.953 & 2.017 & 1.540 \\
\hline 5 & - & 3.852 & 2.392 & 3.931 \\
\hline
\end{tabular}

According to the calculations (Table 3), the amount of cash receipts from the implementation of ALRMS will pay back the initial project costs in the fifth year, the payback period of the project is 5 years.

So, in the direction of "finance" using the key performance indicators of the project, an assessment is given that indicates the prospects of the project and the goal of "profitability of the project" has been achieved.

The next step is to assess the KPI in the direction of "business processes". The first indicator that needs to be assessed is the yardtime of locomotives for emergency repairs. The analysis showed a decrease in yardtime due to the elimination of violations of operating modes and due to the identification of pre-failure conditions during emergency repairs.

\section{Purpose of the Study}

The next indicator to be assessed is the coefficient of technical availability of the locomotive, calculated by the formula (2):

$$
\mathrm{CTA}=\frac{t_{\mathrm{wc}}}{t_{\mathrm{wc}}+t_{\mathrm{ic}}+t_{\mathrm{sch}}},
$$

where $t_{\mathrm{wc}}$ is the total time of the locomotives staying in a working condition in the considered period of operation, hours;

$t_{\text {ic }}$ is the total time spent by locomotives in an inoperative condition for emergency types of repairs in the considered period of operation, hours;

$t_{\mathrm{sch}}$ is the total time of the locomotives staying in an inoperative condition due to their scheduled maintenance and repairs in the considered period of operation, hours;

Analysis of the values of the coefficient of the technical availability of a locomotive by elements showed that a decrease in the locomotive yardtime for emergency repairs should lead to an increase in its value. It should be noted that predicting changes in this indicator is a very difficult task, since it is necessary to take into account many factors that affect both the operating time of locomotives and their yardtime for planned and emergency types of repair, therefore the authors build their predictions on the experience of using ALRMS in the service locomotive depot of the railway station Zima of the East Siberian railway. So, during the use of ALRMS in this depot, it was possible to increase the technical availability coefficient of the locomotive by $1.02 \%$. Therefore, for further research, we will take this value as a basis. Predicted values of the indicator of the locomotive's technical availability coefficient are presented in Table 4.

Table 4. Predicted values of the indicator of the locomotive's technical availability coefficient in the service locomotive depot

\begin{tabular}{|c|c|c|c|c|c|}
\hline \multicolumn{1}{|c|}{ Indicator } & $\begin{array}{l}\text { Year } \\
\mathbf{2 0 2 0}\end{array}$ & $\begin{array}{l}\text { Year } \\
\mathbf{2 0 2 1}\end{array}$ & $\begin{array}{c}\text { Year } \\
\mathbf{2 0 2 2}\end{array}$ & $\begin{array}{c}\text { Year } \\
\mathbf{2 0 2 3}\end{array}$ & $\begin{array}{c}\text { Year } \\
\mathbf{2 0 2 4}\end{array}$ \\
\hline $\begin{array}{l}\text { Locomotive technical } \\
\text { availability coefficient }\end{array}$ & 0.914 & 0.924 & 0.933 & 0.942 & 0.954 \\
\hline
\end{tabular}

\section{Research Methods}

So, the indicators to be assessed within the framework of the BSC system in the direction of "business processes" have been achieved, which in turn leads to the achievement of the set goals:

- reducing the yardtime of locomotives in the process of maintenance and current repair;

- improving the quality of maintenance and current repair of locomotives.

The last and most important indicator when assessing the implementation of an ALRMS project using a 
balanced scorecard is the level of automation. The main goal of automation is to improve quality, while the automated process is more stable than the process performed manually. The automation level is assessed by the authors using a questionnaire survey of experts according to the point system. Representatives of the service locomotive depot and service users will act as experts. The indicators will be assessed by experts based on the following adopted assessment system [4]:

- 0 - the process is poorly organized;

- 1 - the process is satisfactorily organized;

- 2 - the process is well organized.

Data from a questionnaire survey of experts on the level of automation of ALRMS are presented in Table 5.

Table 5. Results of the questionnaire survey of experts

\begin{tabular}{|c|c|c|c|c|c|c|c|c|c|c|}
\hline Direction of assessment & 苞 & 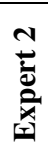 & 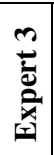 & 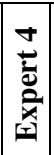 & 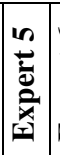 & 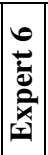 & $\mid$ & 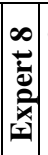 & 产 & 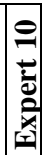 \\
\hline $\begin{array}{l}\text { Fonsistency of the ALRMS } \\
\text { ctions }\end{array}$ & 2 & 1 & 2 & 1 & 2 & 1 & 2 & 1 & 2 & 1 \\
\hline $\begin{array}{l}\text { he level of ALRMS } \\
\text { ntegration into the } \\
\text { production process }\end{array}$ & 1 & 2 & 1 & 2 & 2 & 1 & 2 & 1 & 2 & 2 \\
\hline $\begin{array}{l}\text { he ALRMS integration } \\
\text { evel for coordination with } \\
\text { xisting software platforms }\end{array}$ & 2 & 2 & 2 & 1 & 1 & 2 & 2 & 1 & 2 & 1 \\
\hline \begin{tabular}{|l|} 
ndependence of the \\
ALRMS execution \\
\end{tabular} & 1 & 1 & 2 & 2 & 2 & 2 & 1 & 2 & 2 & 2 \\
\hline $\begin{array}{l}\text { Ooordination of ALRMS } \\
\text { vith the economic } \\
\text { bjectives of the enterprise }\end{array}$ & 1 & 2 & 1 & 2 & 1 & 2 & 1 & 1 & 2 & 2 \\
\hline $\begin{array}{l}\text { Jsing the functionality of } \\
\text { he ALRMS software }\end{array}$ & 2 & 2 & 2 & 1 & 2 & 1 & 2 & 2 & 2 & 1 \\
\hline
\end{tabular}

Further, based on the data in Table 5, we estimate the level of automation using the formula (3):

$\mathrm{A}=\frac{\sum a_{i}}{N \cdot a_{\max }}$

where $\mathrm{A}$ is the level of automation;

$\sum a_{i}$ is the number of points for which the automation was assessed by a specific expert;

$N$ is the number of experts participating in the questionnaire survey, persons;

$a_{\max }$ is the maximum score according to the questionnaire survey results.

The results of the questionnaire survey conducted are presented in Table 6.

Thus, according to (3), the level of automation can be assessed as high.

- $\mathrm{A}=0.2-0.35$ is the low level of automation;

- $\mathrm{A}=0.36-0.65$ is the average level of automation;

- $\mathrm{A}=0.66-1$ is high level of automation.

Further, it is necessary to determine the degree of consistency of experts' opinions through the coefficient of concordance, using well-known methods of mathematical statistics, since if the parameters recommended by statistics are not met by the degree of consistency of opinions, the results of this survey are not taken into account in the future [16]. Calculations of the coefficient of concordance (Table 7), the value of which was 0.635 , indicate a fairly high degree of agreement among experts.

Table 6. Assessment of the level of automation after the implementation of ALRMS

\begin{tabular}{|c|c|c|c|c|}
\hline Direction of assessment & 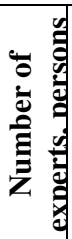 & 苛 & 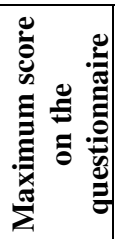 & 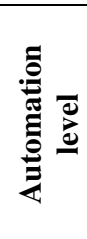 \\
\hline Consistency of the ALRMS actions & \multirow{6}{*}{10} & 15 & 2 & 0.75 \\
\hline $\begin{array}{l}\text { The level of ALRMS integration into } \\
\text { the production process }\end{array}$ & & 16 & 2 & 0.80 \\
\hline $\begin{array}{l}\text { The ALRMS integration level for } \\
\text { coordination with existing software } \\
\text { platforms }\end{array}$ & & 16 & 2 & 0.80 \\
\hline $\begin{array}{l}\text { Independence of the ALRMS } \\
\text { execution }\end{array}$ & & 17 & 2 & 0.85 \\
\hline $\begin{array}{l}\text { Coordination of ALRMS with the } \\
\text { economic objectives of the enterprise }\end{array}$ & & 15 & 2 & 0.75 \\
\hline $\begin{array}{l}\text { Using the functionality of the } \\
\text { ALRMS software }\end{array}$ & & 17 & 2 & 0.85 \\
\hline Average score & & & & 0.80 \\
\hline
\end{tabular}

Table 7. Results of the questionnaire survey of experts

\begin{tabular}{|c|c|c|c|c|c|c|c|c|c|c|c|c|}
\hline $\begin{array}{l}\text { Direction of } \\
\text { assessment }\end{array}$ & 吾 & 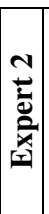 & 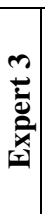 & 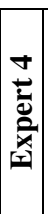 & 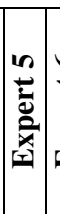 & 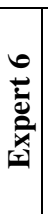 & 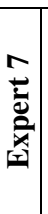 & 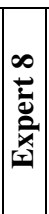 & 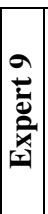 & 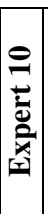 & 吾 & 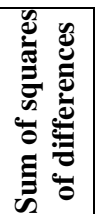 \\
\hline $\begin{array}{l}\text { Consistency of the } \\
\text { ALRMS actions }\end{array}$ & 4 & 5 & 6 & 4 & 4 & 4 & 4 & 2 & 4 & 4 & 41 & 30.25 \\
\hline $\begin{array}{l}\text { The level of } \\
\text { ALRMS } \\
\text { integration into } \\
\text { the production } \\
\text { process }\end{array}$ & 3 & 3 & 3 & 2 & 3 & 3 & 3 & 1 & 3 & 2 & 26 & 90.25 \\
\hline $\begin{array}{l}\text { The ALRMS } \\
\text { integration level } \\
\text { for coordination } \\
\text { with existing } \\
\text { software platforms }\end{array}$ & 2 & 2 & 4 & 3 & 2 & 2 & 2 & 3 & 2 & 1 & 23 & 156.25 \\
\hline $\begin{array}{l}\text { Independence of } \\
\text { the ALRMS } \\
\text { execution }\end{array}$ & 1 & 1 & 1 & 1 & 1 & 5 & 1 & 4 & 1 & 3 & 19 & 272.25 \\
\hline $\begin{array}{l}\text { Coordination of } \\
\text { ALRMS with the } \\
\text { economic } \\
\text { objectives of the } \\
\text { enterprise }\end{array}$ & 5 & 4 & 5 & 5 & 6 & 4 & 5 & 5 & 5 & 5 & 49 & 182.25 \\
\hline $\begin{array}{l}\text { Using the } \\
\text { functionality of } \\
\text { the ALRMS } \\
\text { software }\end{array}$ & 6 & 6 & 2 & 6 & 5 & 6 & 6 & 6 & 6 & 6 & 5 & 380.25 \\
\hline otal & 21 & 21 & 212 & & 212 & 212 & 21 & 21 & 21 & & 213 & 1111.5 \\
\hline
\end{tabular}

\section{Findings}

The main task of innovative projects is not to increase their number, but to increase the long-term efficiency of 
the transport company. To achieve this goal, according to the authors, it is advisable to use the balanced scorecard (BSC), which is an element of the company's strategic management, but it must be adapted to innovative projects. The use of the balanced scorecard in the service locomotive depot of the railway transport system will allow the industry to reach a new level of functioning and make it possible to assess the economic efficiency of innovative projects as objectively and accurately as possible. The proposed methodology for assessing the effectiveness of an innovative project makes it possible, on the one hand, to economically justify the project, on the other hand, to monitor production efficiency both for the purposes of the project itself and to stimulate the innovative activity of the enterprise. With that, the result of an innovative project is considered not as static, but as a set of indicators for its implementation, which has specific dynamic, economic, financial, technical, technological and other characteristics

\section{Conclusion}

The difficult economic conditions in which both the state in general and the railway industry in particular find themselves, the slowdown in economic growth of the industry, and a decrease in traffic volumes require a competent implementation of the policy of effective cost and financial resource management.

The goal of innovative projects implemented in the railway transport system in order to increase the level of its competitiveness in the domestic and foreign transport market is not to increase their number, but primarily to increase the long-term efficiency and smooth operation of the transport company. To achieve this goal, according to the authors, it is advisable to use the balanced scorecard (BSC), which is an element of the company's strategic management, but it must be adapted to innovative projects. On the basis of the proposed methodology, using the balanced scorecard system (BSC) developed by the authors in relation to the service locomotive depot, the economic efficiency of the introduction of the automated locomotive reliability management system (ALRMS) in the railway transport system has been estimated. With regard to the service locomotive depot, it is advisable to use this system with three main indicators: finance, internal business processes and personnel management. All the goals set within the BSC have been achieved, which indicates the effectiveness and success of the ALRMS project being implemented.

\section{References}

1. L.V. Eichler, M.A. Zotkina. Improvement of cost management methodology for a freight road transport enterprise in modern conditions. Economiczne nauki. Przemysl: Nauka i studia. Materialy VII Miedzynarodowej naukowipraktycznej konferecji "Dynamika naukowych badan, vol. 3 (2011), pp. 80-84
2. N.N. Grigorieva, V.A. Olentsevich, N.P. Astashkov. Formation of new principles and models of the industry structural units in the context of the introduction of digital technologies. Modern technol. Syst. Anal. Model, 65(1), 156-165 (2020). DOI: 10.26731/1813-9108.2020.1(65).156-165.

3. The Development Strategy of Russian Railways Holding for the period until 2030 (Rus. Railways OAO, Moscow, 2013)

4. S.G. Kamshilov. Determination of the level of automation of business processes at an industrial enterprise. Bull. of the Chelyabinsk State Univ., 1, 56-61 (2015)

5. R. Kaplan, D. Norton. Balanced Scorecard (Biznes Olymp Publ., Moscow, 2002)

6. N.V. Krol, N.N. Grigoryeva, V.A. Olentsevich, R.Yu. Upyr. Ways to improve the economic mechanism in the development of the customer base of freight traffic. Modern technol. Syst. Anal. Model., 4(64), 155-161 (2019)

7. Maintenance of rolling stock in European countries. World Railways, 4, 50-53 (2009)

8. N.L. Mikhalchuk. The relevance of the development of a locomotive repair complex in the transition to full maintenance service. Prospects for the development of locomotive service. Mat. of the First Int. sci. and pract. conf. (TMKh-Service, Moscow, 2014)

9. D. Norton. Implementation of BSC: advice from the author of the concept. Finan. Direct., 4 (2006)

10. Official site Russian Railways OAO. Retrieved from: www.rzd.ru

11. V.A. Olentsevich, N.P. Astashkov. Methods of attracting customers to the services of the transport and logistics business unit in order to increase the competitiveness of the Russian Railways holding company. Transp. Infrastruct. of the Siber. Reg., 1, 4-8 (2019)

12. M. Porter. Competitive strategy: methods for analyzing industries and competitors. Trans. from English (Alpina Business Books, Moscow, 2007)

13. N.I. Pyzhyanov. On the way to high-quality service maintenance of the locomotive fleet (domestic and foreign experience). Online magaz. "Sci. Stud.", 8(3) (2016)

14. Prospects for the development of locomotive service. Mat. of the First Int. sci. and pract. Conf. (TMKhService OOO, Moscow, 2014)

15. G.V. Silicheva, N.I. Pyzhyanov. Problems and prospects of development of the locomotive repair complex of "Russian Railways" OAO. Modern technol. Syst. Anal.. Model., 2(46), 143-147 (2015)

16. M.A. Zotkina. Formation of cost management costs based on a balanced scorecard. In: Actual problems of economics and management of Russian enterprises. The collection of scientific papers, vol. 4 (pp. 43-48) (SibADI Publ., Omsk, 2009) 